\title{
Experiment of Polylactic Acid as a Material for Candle Molding on Origami-Shaped Crash Box Patterns \\ Kusyairi I. ${ }^{1 *}$, Himawan H. M. ${ }^{1}$, Choiron M. A. ${ }^{2}$, Irawan Y. S. ${ }^{2}$ \\ ${ }^{1}$ Politeknik Kota Malang, 3 Jalan Raya Tlogowaru, 65141 Malang, Indonesia; \\ ${ }^{2}$ Universitas Brawijaya, Jalan Veteran, 65145 Malang, Indonesia
}

Article info:

Paper received:

The final version of the paper received:

Paper accepted online:
October 15, 2018

December 3, 2018

December 7, 2018
*Corresponding Author's Address: kusyairi1408@gmail.com

\begin{abstract}
This paper study experiment by utilizing Polylactic Acid (PLA) which was printed with 3D Printing technology by taking the form of origami-shaped crash box pattern designed for MPV cars. The first step is to design crash box origami patterns with CAD software, and continue with the mold wax design. Then print the model in the Cura software. Then print the mold with approximately 56 hours 31 minutes and spend a $16.38 \mathrm{~m}$ long PLA filament weighing $128 \mathrm{~g}$. Then pour wax, as for the wax used is carnauba wax with the temperature of pouring into the mold approximately $110^{\circ} \mathrm{C}$, let it chilled for 11 minutes then the mold is released from the wax. The final step is inspection. The result of this experiment is that the PLA-based mold is capable of printing the origami-shaped crash box pattern well, shown by clear printing of sharp indentations both inside and outside. Percentage of nonconformity with design area $\mathrm{A}$ of $0.52 \%$, area $\mathrm{B}$ of $0.43 \%$, area $\mathrm{C}$ of $0 \%$, area D of $10.8 \%$, area of E1-4 of $0 \%$ and area E5 of $3.2 \%$ are obtained. A comparison of the overall size of the design with the experiment was $0.29 \mathrm{~mm}$. PLA tends to show consistency of experimental results. This is shown in the consistency of experimental results 1 to 3 in areas A, $\mathrm{B}, \mathrm{C}$ and $\mathrm{E}$. But there are inconsistencies in the experimental results in area $\mathrm{D}$ which represents the thickness dimension. This is influenced by changes in mold patterns which are affected by temperature pour wax into the mold and trigger the change of mold due to heat received continuously.
\end{abstract}

Keywords: carnauba wax, mold, PLA, sharp indentation, crash box pattern.

\section{Introduction}

Investment casting is a metal casting process with results having high precision. This method is used to produce several diverse and complex industrial components (Huang and Lin, 2015). This consists of several processes, namely: making wax patterns, coating ceramic porridge, and pouring (Liu et. at, 2015). In the process of making mold wax, in some industries using iron so that the resulting pattern can be precise. However, wax molds made of iron requires a high cost for some circles. The researchers conducted experiments to solve this issue, using silicone rubber-based wax molds (Kuo and Shi, 2012). The advantages of rubber-based silicon molds producing precised assembly and $2.19 \%$ shrinkage dimensions. As it develops, the silicone rubber mold is given by the taguchi method, producing optimal temperature in the tax process is the injection temperature of $82^{\circ} \mathrm{C}$, injection time of 2 seconds, injection pressure of $0.06 \mathrm{MPa}$ and mold temperature of $60^{\circ} \mathrm{C}$ (Kuo and Tsai,
2015). Other study produced an optimal temperature of $5{ }^{\circ} \mathrm{C}$ mold temperature, $85{ }^{\circ} \mathrm{C}$ for wax temperature, at 5.05 MPa (Rahmati et. al., 2007). The research also developed for aluminum-filled of epoxy resin mold. The main benefits of this technique include low production costs, a simple manufacturing process, and a short time of total process (Kuo et. al., 2017). At present the threedimensional (3D) printer moves are fast, not least in engineering. Some researchers conducted research using 3D printers combined with changing the material phase for making wax molds (Wang and Millogo, 2012).

In this paper, mold wax is made using $3 \mathrm{D}$ printing and filament made from Polylactic Acid (PLA) which includes aliphatic polyester biodegradable thermoplastic material. To test the ability to print complex and thin objects, a candle pattern in the form of a crash box origami pattern is used. 


\section{Research Methodology}

\subsection{CAD modelling}

The pattern used in this paper is the origami-shaped crash box pattern (Ma and You, 2013) which has been modified to be applied to the MPV (Multi-Purpose Vehicle) Car which circulates in Indonesia (Kusyairi, 2017). This experiment prints half of the origami pattern crash box, as seen in Figure 1. The cross section is rectangular in shape and has a thickness of $3 \mathrm{~mm}$ in all parts. This will be a challenge when pouring wax into the mold, which has sharp angles and curves.

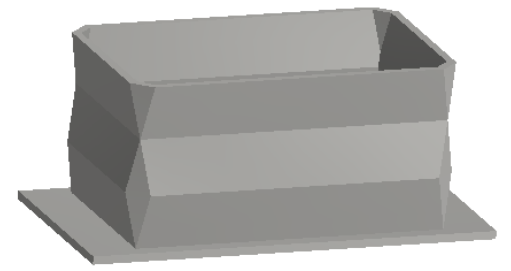

Figure 1 - Origami-shaped crash box pattern

The mold wax design in this paper is as shown in Figure 2. In Figure 2.a, it is divided into 2 parts, the inside and the outer parts of the mold. In the inner mold, the outline consists of two parts, but the actual part is the most complicated part, because in the $3 \mathrm{D}$ printing process it is divided into 5 parts. This is so that the mold is easily removed and does not have to damage the wax. The outer mold generally consists of 1 part, but in the 3D Printing process is divided into 2 parts, where between the inner and outer mold is connected to the nut so that there is no shift when pouring wax into the mold.

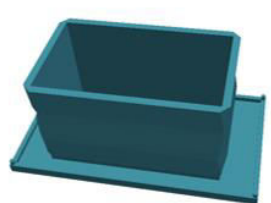

a

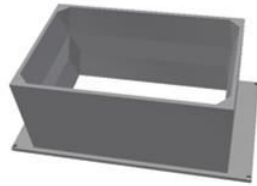

b

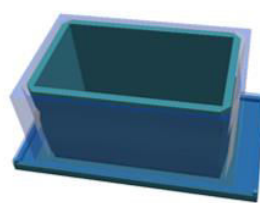

Figure 2. Origami-shaped crash box pattern mold: $\mathrm{a}$ - inner part; $\mathrm{b}$ - outer part; $\mathrm{c}$ - mold hilistically

\subsection{D printing process}

After designing the pattern of the object to be printed and the mold wax design, the next step is to print the mold with 3D Printing which is operated with cura software. The material used is PLA and its properties can be seen in Table 1. Setting the cura software by entering temperature data of $240{ }^{\circ} \mathrm{C}$, diameter of $1.75 \mathrm{~mm}$ at a speed of $30 \mathrm{~mm} / \mathrm{s}$. The time required for the mold making process is 56 hours 31 minutes and consumes a $16.38 \mathrm{~m}$ PLA filament weighing $128 \mathrm{~g}$. The results of the 3D Printing process can be seen in Figure 3, with a not-sosmooth surface.
Table 1 - Material properties of PLA (Farbman, McCoy, 2016)

\begin{tabular}{|l|c|}
\hline \multicolumn{1}{|c|}{ Properties } & Parameters \\
\hline Melting Point & $175^{\circ} \mathrm{C}$ \\
\hline Density & $1.23-1.25 \mathrm{~g} / \mathrm{cm}^{3}$ \\
\hline Elongation at Break & $3.8 \%$ \\
\hline Glass Transition & $60-65^{\circ} \mathrm{C}$ \\
\hline Tensile Strength & $57.8 \mathrm{MPa}$ \\
\hline Flexural Strength & $55.3 \mathrm{MPa}$ \\
\hline Tensile Modulus & $3.3 \mathrm{GPa}$ \\
\hline Flexural Modulus & $2.3 \mathrm{GPa}$ \\
\hline
\end{tabular}

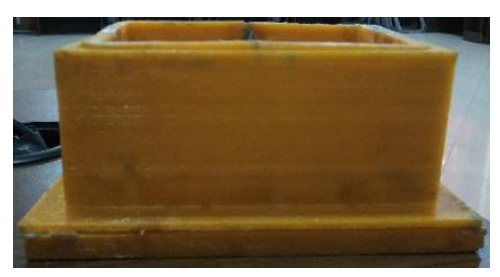

Figure $3-3 D$ Printing result

\subsection{Wax pouring}

In this experiment, carnauba wax material is used. This material was obtained from palm trees that grow in Brazil with the Latin name Copernicia pruniferacerifera. The content of these waxes are fatty esters (80-85\%), free alcohols (10-15\%), acids (3-6\%) and hydrocarbons (1-3\%) (Sandhu and Sharma, 2012). Carnauba wax is widely used in the investment casting process because it has high dimensional accuracy. The carnauba wax property material is shown in Table 2. After the mold has been printed, the next step is to coat the mold with a nonsticky liquid, which functions to make the wax easily separated from the mold. The next step is heating the wax to a temperature of $85-120{ }^{\circ} \mathrm{C}$. After a while, the wax is poured into the mold and is chilled for 11 minutes. Next, separating the mold one by one from wax.

Table 2 - Material properties for a carnauba wax (Rani, 2013)

\begin{tabular}{|c|c|c|c|}
\hline Density & Melting point & $\begin{array}{c}\text { Flash } \\
\text { Point }\end{array}$ & $\begin{array}{c}\text { Volumetric } \\
\text { shrinkage }\end{array}$ \\
\hline $970 \mathrm{~kg} / \mathrm{m}^{3}$ & $82-86^{\circ} \mathrm{C}$ & $300{ }^{\circ} \mathrm{C}$ & 5.45 \\
\hline
\end{tabular}

\subsection{Inspection}

After the wax has been printed 3 times, the next step is measuring the experimental results. The measured area is as shown in Figure 4. It consists of five areas to be measured, in area A represents the long dimension, area B represents the width dimension, area $C$ represents the high dimension, area $\mathrm{D}$ represents the thick dimension, and area E represents the angular dimension. After the measurement process, the next step is to calculate the percentage dimension mismatch $P D D=(\Delta y / x) \cdot 100 \%$, where $x$ - design dimensions; $\Delta y-$ the differences of design and result dimensions. 

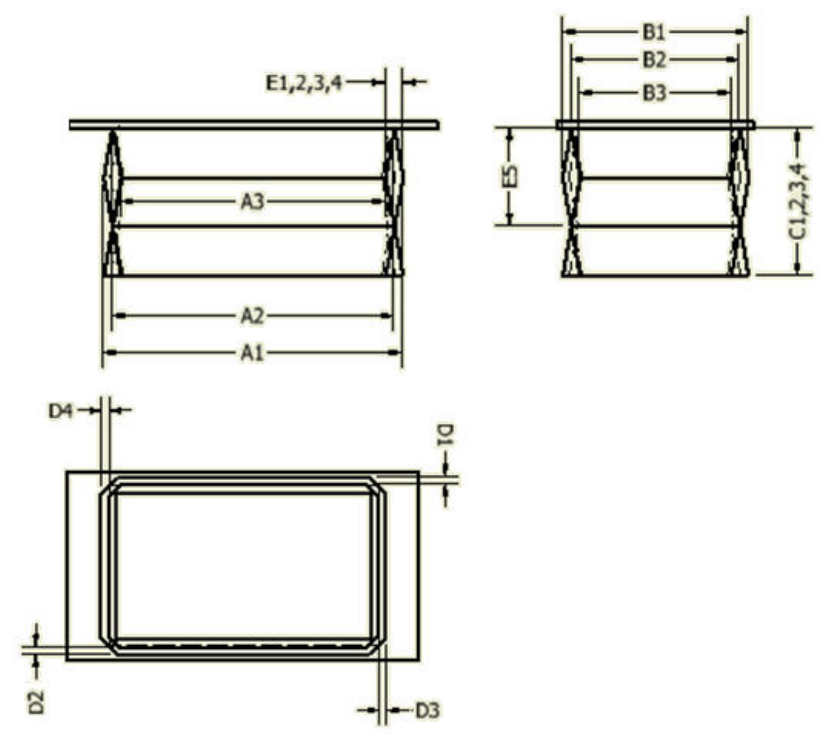

Figure 4 - Measurement area:

A1 - length of distance between the outer corner; A2 - length of distance between the middle angles; A3 - length of distance between inner angles; B1 - width The distance between the outer corner; B2 - width distance between the middle angles; B3 - width distance between inner angles; C1-4 - height of objects; D1-4 - thicknesses; E1-4 - angular width; E5 - high angle

\section{Results}

Experiment results can be seen in Figure 5. It looks like the pattern has been successfully printed; this is evidenced by the formation of wax in accordance with the design. The inside of the experiment results can follow the outer grooves so well that the inner sharp angles are able to form, this can be seen in Figure 5.a. On the outside, the shape matches the design and the curve of the angular pattern is able to form, this can be seen in Figure 5.b and 5.c. The roughness of the wax surface tends to follow from the surface structure of the mold. In this experiment, the molds made from PLA from the 3D process have a non-smooth surface. This affects the results of the smooth surface of the wax.

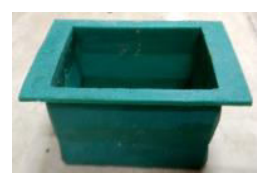

$\mathrm{a}$

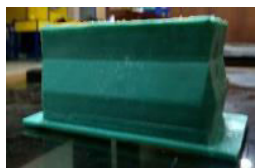

b

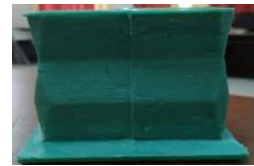

c
Figure 5 - Experimental results: top (a), front (b) and side (c) views

In Table 3, there is a comparison of the size and percentage of non-conformity with the experiment. In area $\mathrm{A}$ which represents the long dimension, the percentage of non-conformity with the design is $0.52 \%$, in area $\mathrm{B}$ is $0.43 \%$, in area $\mathrm{C}$ is $0 \%$, in area $\mathrm{D}$ is $10.8 \%$, in the area of E1-4-0\% and in the E5 area the height of the angle is $3.2 \%$.

Data Table 3 shows that PLA can be used as a waxmaking mold. This is evidenced by the comparison of the overall size of the design with the experiment of $0.29 \mathrm{~mm}$, as shown in Figure 6. Mold wax made from PLA has an average difference with experiments in the length dimension $0.6 \mathrm{~mm}$, width of $0.17 \mathrm{~mm}$, height of $0.05 \mathrm{~mm}$ and thickness of $0.65 \mathrm{~mm}$. This means that PLA can be used for parts that have a tolerance below $1 \mathrm{~mm}$.

Table 3 Results of the size experiment and presentation of non-conformity design

\begin{tabular}{|c|c|c|c|c|c|c|c|c|c|c|}
\hline \multirow{2}{*}{ Area } & \multirow{2}{*}{$\begin{array}{c}\text { Design } \\
\text { size }\end{array}$} & $\begin{array}{c}\text { Size, } \\
\mathrm{mm}\end{array}$ & $\begin{array}{c}\text { Percentage } \\
(\%)\end{array}$ & $\begin{array}{c}\text { Size, } \\
\mathrm{mm}\end{array}$ & $\begin{array}{c}\text { Percentage, } \\
\%\end{array}$ & $\begin{array}{c}\text { Size, } \\
\mathrm{mm}\end{array}$ & $\begin{array}{c}\text { Percentage, } \\
\%\end{array}$ & $\begin{array}{c}\text { Average } \\
\text { size, mm }\end{array}$ & $\begin{array}{c}\text { Average } \\
\text { difference, } \\
\mathrm{mm}\end{array}$ & $\begin{array}{c}\text { Average } \\
\text { percentage, } \\
\mathrm{mm}\end{array}$ \\
\hline A1 & 121.5 & 119.5 & 1.6 & 119.5 & 1.6 & 119.5 & 1.6 & 119.5 & 2.0 & 1.6 \\
\hline A2 & 114.5 & 112.7 & 1.6 & 112.7 & 1.6 & 112.7 & 1.6 & 112.7 & 1.8 & 1.6 \\
\hline A3 & 107.0 & 106.0 & 0.9 & 106.0 & 0.9 & 106.0 & 0.9 & 106.0 & 1.0 & 0.9 \\
\hline B1 & 75.5 & 75.0 & 0.7 & 75.0 & 0.7 & 75.0 & 0.7 & 75.0 & 0.5 & 0.7 \\
\hline B2 & 68.5 & 69.0 & -0.7 & 69.0 & 0.7 & 69.0 & -0.7 & 69.0 & -0.5 & -0.2 \\
\hline B3 & 61.4 & 62.0 & 1.0 & 62.0 & 1.0 & 62.0 & 1.0 & 62.0 & -0.6 & 1.0 \\
\hline C1 & 60.0 & 60.0 & 0.0 & 60.0 & 0.0 & 60.0 & 0.0 & 60.0 & 0.0 & 0.0 \\
\hline C2 & 60.0 & 60.0 & 0.0 & 60.0 & 0.0 & 60.0 & 0.0 & 60.0 & 0.0 & 0.0 \\
\hline C3 & 60.0 & 60.0 & 0.0 & 60.0 & 0.0 & 60.0 & 0.0 & 60.0 & 0.0 & 0.0 \\
\hline C4 & 60.0 & 60.0 & 0.0 & 60.0 & 0.0 & 60.0 & 0.0 & 60.0 & 0.0 & 0.0 \\
\hline D1 & 3.0 & 3.0 & 0.0 & 3.0 & 0.0 & 3.0 & 0.0 & 3.0 & 0.0 & 0.0 \\
\hline D2 & 3.0 & 3.4 & 13.3 & 3.2 & 6.7 & 3.0 & 0.0 & 3.2 & -0.2 & 6.7 \\
\hline D3 & 3.0 & 3.4 & 13.3 & 3.8 & 26.7 & 3.4 & 13.3 & 3.5 & -0.5 & 17.8 \\
\hline D4 & 3.0 & 3.6 & 20.0 & 3.9 & 30.0 & 3.2 & 6.7 & 3.6 & -0.6 & 18.9 \\
\hline E1 & 10.0 & 10.0 & 0.0 & 10.0 & 0.0 & 10.0 & 0.0 & 10.0 & 0.0 & 0.0 \\
\hline E2 & 10.0 & 10.0 & 0.0 & 10.0 & 0.0 & 10.0 & 0.0 & 10.0 & 0.0 & 0.0 \\
\hline E3 & 10.0 & 10.0 & 0.0 & 10.0 & 0.0 & 10.0 & 0.0 & 10.0 & 0.0 & 0.0 \\
\hline E4 & 10.0 & 10.0 & 0.0 & 10.0 & 0.0 & 10.0 & 0.0 & 10.0 & 0.0 & 0.0 \\
\hline E5 & 40.0 & 38.7 & 3.2 & 38.7 & 3.2 & 38.7 & 3.2 & 38.7 & 1.3 & 3.2 \\
\hline
\end{tabular}




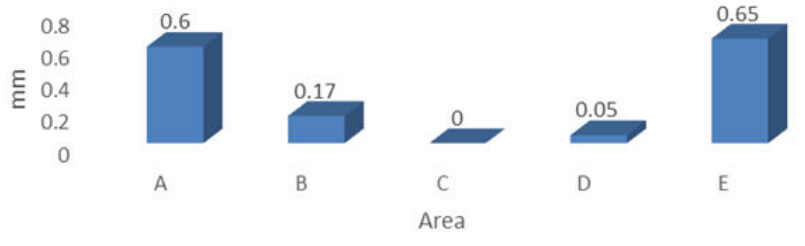

Figure 6 - Average difference between the design and experiments

Table 3 shows the consistency of experimental results 1 to 3 . It can be seen that the results of the area A1 of the overall wax pattern consistently produce a measurement of $119.5 \mathrm{~mm}$. Likewise for A2 and A3 areas produce consistent sizes. In area $\mathrm{B}$, there is also a consistent measurement between the first experiment and the third. In area $\mathrm{C}$, which represents a high dimension, it is consistent with all experimental results and also in accordance with the size of the design. PLA-based molds are also able to form angles consistently, this can be seen in the E1-4 areas which still show the same size in each experiment, and more than that the resulting dimensions are the same as the design size. This can be seen further in Figure 7, which shows the constitution of experimental results.

But this is different from area D which represents the thickness dimension; there are inconsistencies size of experimental result 1,2 and 3. This is due to the PLA pattern that has shaped mold wax has changed. The first change occurs when the mold is finished with 3D Printing, the second change occurs when the mold is poured into wax which reaches a temperature of approximately $110{ }^{\circ} \mathrm{C}$. This makes PLA experience a sideways change in shape, where the inner and outer molds are narrowed and widened. This can be seen when experiments 1, 2, and 3 results vary. Form changes can be reduced by enlarging the thick dimensions of the mold.

PLA is able to form a wax pattern that has the complexity of objects with the same results in each process, but this is only to produce in small quantities. If used continuously with quantity equated with molds made of metal, PLA-based mold will change shape and will produce products that are not precise anymore. Continuous heat when pouring wax into molds made from PLA will cause the mold to change shape continuously, this is what will cause inconsistency.

\section{Conclusions}

PLA-based molds are able to print origami pattern crash box well, this can be seen by the clear printing of sharp indentations both inside and outside. But the surface does not have a smooth surface, this is because following the results of the surface roughness of 3D Printing products. It is necessary to examine more effective ways to smooth the surface of the results of 3D Printing.

Percentage of nonconformity with design area $\mathrm{A}$ at $0.52 \%$, area $\mathrm{B}$ at $0.43 \%$, area $\mathrm{C}$ at $0 \%$, area $\mathrm{D}$ at $10.8 \%$, area E1-4 at $0 \%$ and area E5 - at $3.2 \%$.

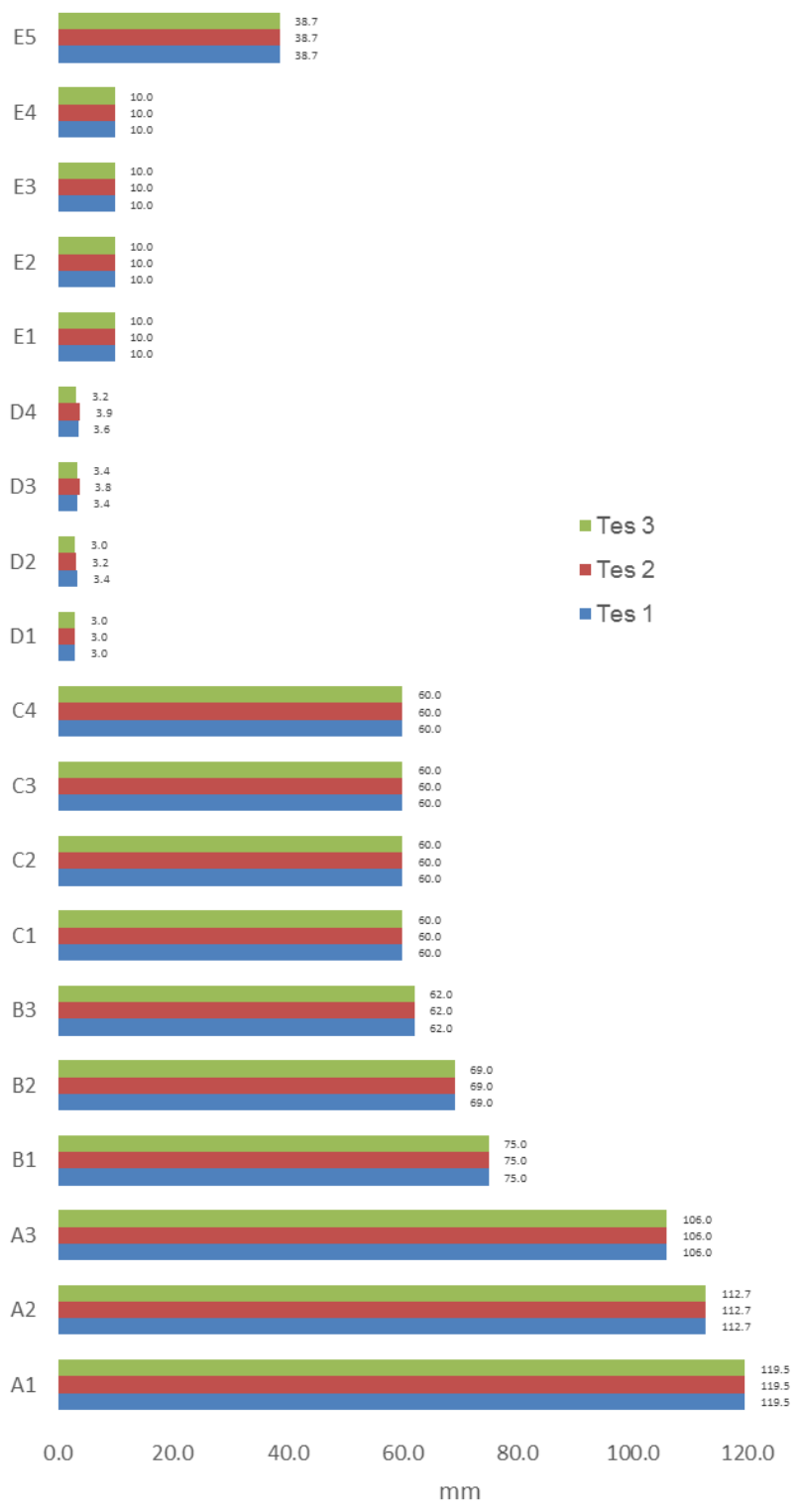

Figure 7 - Consistency of the experimental results

PLA can be used as a mold composition used for wax making. This is evidenced by the comparison of the overall size of the design with the experiment of $0.29 \mathrm{~mm}$.

PLA tends to show consistency of experimental results. It is shown in areas A, B, C and E that there is consistency of experimental results 1 to 3 , but in contrast to area $\mathrm{D}$ which represents the thickness dimension, there is an inconsistency in the experimental results. This is due to the pattern of PLA that has been shaped as mold wax has changed. The first change occurs when the mold is finished with 3D Printing, the second change occurs when the mold is poured into wax which reaches a temperature of approximately $110{ }^{\circ} \mathrm{C}$. This makes PLA experience a sideways change in shape, where between the inside mold and the outer mold is narrowing and widening. This can be seen when experimentations 1, 2 and 3 result vary. Form changes can be reduced by enlarging the thick dimensions of the mold. 


\title{
5 Acknowledgements
}

The researchers would like to express a deep gratitude to the Ministry of Research, Technology and Higher Education, the Directorate General of Strengthening Research and Development, and the Directorate of Research and Community Service that has financed the entire research, Announcement 0045/E3/LL/2018, January 16, 2018.

\section{References}

1. Farbman, D, \& McCoy, C. (2016). Materials Testing of 3D Printed ABS and PLA Samples to Guide Mechanical Design. ASME International Manufacturing Science and Engineering Conference, Vol. 2, V002T01A015, doi: 10.1115/MSEC2016-8668.

2. Huang, P.-H., \& Lin, C.-J. (2015). Computer-aided modeling and experimental verification of optimal gating system design for investment casting of precision rotor. International Journal of Advanced Manufacturing Technology, Vol. 79(5-8), pp. 9971006, doi: 10.1007/s00170-015-6897-5.

3. Kuo, C.-C., Chen, W.-H., \& Xu, W.-C. (2017). A cost-effective approach for rapid manufacturing wax injection molds with complex geometrical shapes of cooling channels. International Journal of Advanced Manufacturing Technology, Vol. 91(5-8), pp. 1689-1695, doi: 10.1007/s00170-016-9886-4.

4. Kuo, C.-C., \& Shi, Z.-S. (2012). Fabrication of a high precision silicon rubber mold for replicating wax patterns of cylinder heads. Indian Journal of Engineering and Materials Sciences, Vol. 19, pp. 157-162.

5. Kuo, C.-C., \& Tsai, R.-L. (2015). Fabrication and Application of Low-pressure Wax Injection Rapid Toolings. Polymers and Polymer Composites, Vol. 23(9), pp. 647-652.

6. Kusyairi, I. (2017). The Influence Of Origami And Rectangular Crash Box Variations On MPV Bumper With Offset Frontal Test Examination Toward Deformability. Journal of Energy, Mechanical, Material and Manufacturing Engineering, Vol 2, No. 2, pp. 1-8.

7. Liu, C., et al. (2015). Influence of complex structure on the shrinkage of part in investment casting process. International Journal of Advanced Manufacturing Technology, Vol. 77(5-8), pp. 1191-1203, doi: 10.1007/s00170-014-6523-y.

8. Ma, J., \& You, Z. (2013). Energy Absorption of Thin-Walled Square Tubes With a Prefolded Origami Pattern - Part I: Geometry and Numerical Simulation. ASME Journal of Applied Mechacics, Vol. 81(1), art. no. 011003-011003-11, doi: 10.1115/1.4024405.

9. Rahmati, S., Akbari, J., \& Barati, E. (2007). Dimensional accuracy analysis of wax patterns created by RTV silicone rubber molding using the Taguchi approach. Rapid Prototyping Journal, Vol. 13(2), pp. 115-122, doi: 10.1108/13552540710736803.

10. Rani, D. (2013). Recycling of Pattern Wax In The Investment Casting Process Using Microwave Dewaxing. IOSR Journal of Engineering, Vol. 3, pp. 5-10, doi: 10.9790/3021-03520510.

11. Sandhu, C. S., \& Sharma, A. (2012). Investigation Of Optimize Wax Pattern In The Investment Casting By Using The Different Form Of Waxes. IOSR Journal of Mechanical and Civil Engineering, Vol. 3(4), pp. 1-6, doi: 10.9790/1684-0340106.

12. Wang, S., \& Millogo, J. (2012). Rapid prototype mold for wax patterns with the help of phase change materials. International Journal of Advanced Manufacturing Technology, Vol. 62(1-4), pp. 35-41, doi: 10.1007/s00170-011-3784-6.

\section{Дослідження полілактиду як матеріалу для свічкового лиття в руйнівних шаблонах у формі орігамі}

\author{
Кусяірі I. ${ }^{1}$, Хімаван Х. М. ${ }^{1}$, Хоірон М. А. ${ }^{2}$, Іраван Й. С. ${ }^{2}$ \\ ${ }^{1}$ Державний політехнічний інститут м. Маланг , вул. Джалан Сукарно Хатта, 9, 65141, м. Маланг, Індонезія; \\ ${ }^{2}$ Університет Бравіджайа, вул. Джалана, 65145, м. Маланг, Індонезія
}

\begin{abstract}
Анотація. Стаття присвячена експериментальним дослідженняи полілактиду, надрукованого за технологією тривимірного друку руйнівного шаблону формі орігамі, призначеного для автомобільної промисловості. Перший етап досліджень присвячений моделюванню шаблона 3 подальшим проектуванням форми для свічкового лиття із застосуванням відповідного програмного забезпечення. Другий етап стосується лиття приблизно 56 год. і 31 хв. з витратами волокон полілактиду довжиною 16,38 м вагою 128 г. Після виливання карнаубського воску 3 температурою розливання у прес-форми $110{ }^{\circ} \mathrm{C}$, матеріал охолоджується впродовж 11 хв., після чого форма виділяється. На останньому кроці відбувається перевірка. У результаті експерименту встановлено, що форма з полілактиду здатна відбивати добре виражений рисунок руйнівного шаблону. Підтверджене чітке відбиття різких відступів як внутрішніх, так і зовнішніх. Відсоткова невідповідність форми у зоні А складає $0,52 \%, \mathrm{~B}-0.43 \%, \mathrm{C}-0 \%, \mathrm{D}-10.8 \%$, Е1-4 - 0\% і Е5 - $3.2 \%$. Порівняльний аналіз підтвердив загальне відхилення форми від експериментальних даних 0,29 мм. Таким чином, продемонстрована послідовність експериментальних досліджень полілактиду в зонах А, В, С і Е. Проте $\epsilon$ невідповідність експериментальних даних у зоні D, що відповідає за товщину, у результаті зміни форми шаблона під впливом температури розливання воску.
\end{abstract}

Ключові слова: карнаубський віск, форма, полілактид, різкий відступ, руйнівний шаблон. 